\title{
The Development of Buddhism in Australia and New Zealand
}

\author{
Abstract: \\ Buddhism's development in both Australia and New Zealand has increased dramatically in the \\ last twenty years. Buddhism in Australia and New Zealand reflects many of the trends that have \\ been identified in Buddhism's growth in other Western countries; however, some regional \\ differences also exist. This chapter examines the demographics and history of Buddhism in \\ Australia and New Zealand to demonstrate this. The current status of Buddhism in these \\ religiously plural nations is also discussed, particularly in relation to the extent to which this \\ formerly foreign religion is becoming considered part of the mainstream.
}

\section{Paper}

Buddhism has recently undergone substantial growth in both Australia and New Zealand, as it has in many Western countries. The geographical and cultural proximity of these two countries often causes similarities between them to be assumed; however, this paper examines the development of Buddhism in each separately as a means of demonstrating how differences between these two cultures are reflected in slightly differing histories and Buddhist demographics. The sociocultural factors that have enabled this expansion are focused on as a means of illustrating how the developing forms of Buddhism reflect the cultures in which they are now situated. In its early days in the West Buddhism was considered an alien religion; however, contemporary Buddhist practice in Australia and New Zealand is becoming more and more mainstream.

According to the 1996 Australian Bureau of Statistics census, 1.1\% of the population, or 199,812 people, identified themselves as Buddhist. This represented an increase of $42.9 \%$ from the 1991 census. In 1996, 0.8\% of the New Zealand population, or 28,131 people, identified as Buddhists in the Statistics New Zealand census, an enormous $120 \%$ increase over the 1991 census figure.

There are few historical accounts exploring the reasons behind the current state of affairs. 
Croucher provides an excellent historical narrative on Buddhism in Australia, but other Australian sources are scarce. ${ }^{1}$ However, Australian sources are a font of information when compared to the published material on the history of Buddhism in New Zealand. Ajahn Viradhammo's chapter on Buddhism in New Zealand includes several pages of history (in addition to the routine explanations of Buddhist doctrines and practices); this currently comprises the authoritative (that is, only) published work in the area. ${ }^{2}$

Buddhism came to both countries through immigration in the mid-1800s. Buddhism probably first reached Australia in 1848 and New Zealand in 1863, when Chinese immigrants arrived to work in the goldfields. However, in both countries this early influence was slight. The first organisations did not form until some time later. The first Buddhist organisation in Australia was the Little Circle of Dharma, founded in Melbourne in 1925; the second was the Buddhist Study Group in 1938. The first Buddhist organisation in New Zealand is hard to identify due to the lack of information; however the Buddhist Society of New Zealand founded in 1956 was certainly one of the earliest. While early versions of Buddhism in both countries followed the Western pattern of being secular in orientation, focusing on Buddhist texts or philosophy, this slowly changed as more and more teachers from various traditions visited. The first teacher to visit Australia was Sister Dhammadinna in 1952. Teachers from other traditions followed, such as U Thittila, a Burmese Theravada monk, in 1954; and Daisaku Ikeda, president of Soka Gakkai International, in 1964. In New Zealand, monks and lay-teacher from various traditions come in the 1970s, including Karma Tenzin Dorje Namgyal Rinpoche of the Karma Kagyu lineage in 1973; Zen Master Joshu Sasaki Roshi, founder and Abbot of Rinzai-ji, in 1974; and Lama Thubten Yeshe and Lama Thubten Zopa of the Foundation for the Preservation of the Mahayana Tradition in 1975. At the same time, interest in meditation was rising in both countries and many more groups were forming in a variety of traditions.

Due to the continually rising interest, residential teachers and monasteries began to appear. In 1971 the Venerable Somaloka, a Sri Lankan monk, moved to Australia and in 1973 he established the Australian Buddhist Vihara as the first Buddhist monastery in Katoomba, New South Wales. In 1974, an English born, Thai-trained monk, Khantipalo Thera, established a second Theravada monastery, Wat Buddharangsee in Stanmore, New South Wales. Australia is 
now home to the largest Buddhist temple in the Southern Hemisphere. Located in Wollongong, New South Wales, the Nan Tien Temple is part of the Fo Kuang Shan school of Buddhism. The temple complex was built between 1990 and 1996; most of its AUD \$50 million construction cost was donated by Fo Kuang Shan members in Taiwan. The complex includes an eight-storey pagoda, Pilgrim Lodge (with one hundred rooms of three to four star rated accommodation), conference hall, museum, café, bookshop, teahouse and multiple gardens. The temple is becoming so well known that in 1999 it was a finalist in the "significant regional attraction" category of the NSW Tourism Awards.

Exact information is again not available for New Zealand; however, early residential teachers include Dharmachari Achala, an Englishman living in New Zealand who ordained in the World Buddhist Order in New Zealand in 1975; and the Venerable Lama Karma Samten Gyatso, who has been the resident teacher of the New Zealand Karma Kagyu Trust center since 1981. The Venerable Lama Samten and the Venerable Lama Karma Shedrup Senge were ordered in 1979 by the16th Gyalwa Karmapa to begin teaching in New Zealand, and have since established two centers. One of the earliest monasteries established was Bodhinyanarama, a Thai Forest Tradition monastery established near Wellington in 1986.

While many of the early Buddhist groups were convert ${ }^{3}$ in orientation, increased Asian immigration changed the scene. With the ending of the Vietnam War in 1974-75, large numbers of refugees from Laos, Cambodia and Vietnam arrived in Australia. Immigration to New Zealand from southeast Asian countries grew in the early 1980s. With the plethora of traditions and lineages now present in both countries, ecumenical Buddhist societies also increased. A major ecumenical body, the Buddhist Federation of Australia, had formed in 1958, but a number of other ecumenical bodies formed in Australia in the 1980s, such as the Buddhist Council of Brisbane in 1982, and the Buddhist Council of New South Wales in 1985. In New Zealand, the Wellington Buddhist Association formed in 1981, although there may have been earlier incarnations that have not been documented. Another organisation, the Pan Buddhist Association was started in 1990. Australian ecumenical groups have achieved far more than their New Zealand counterparts, probably due to the greater number of Buddhist groups in Australia. For example, the Buddhist Council of New South Wales provides assistance on matters ranging from 
immigration and local government matters, to religious instruction to Buddhist students in State schools, as the Department of School Education's recognized accrediting body for Buddhism teachers. The Buddhist Council of New South Wales was accepted as a Regional Centre of the World Fellowship of Buddhists in Bangkok in 1994 in Bangkok, Thailand. ${ }^{4}$

Buddhism's development has undergone similar periods in both Australia and New Zealand, although many major events occurred approximately ten years later in New Zealand than in Australia. However, this is to be expected from a country that has one-fifth of Australia's population and is even more geographically isolated. The last stage of historical development has been the continuing diversification and growth of Buddhist groups in each country. In June 2000 BuddhaNet provided a listing of 315 Australian Buddhist groups, compared to approximately 60 in New Zealand in $2000 .^{5}$ These figures are almost equal in statistical terms when compared to the countries' populations. The two countries have similar breakdowns of the major Buddhist traditions and lineages present, as demonstrated by Table 1.

Table 1: Traditions/Lineages Represented by

Australian and New Zealand Buddhist Groups in 2000

\begin{tabular}{|l|c|c|}
\hline & Australia (2000) & New Zealand (2000) \\
\hline Theravada & $25 \%$ & $29 \%$ \\
\hline Mahayana & $34 \%$ & $40 \%$ \\
\hline Vajrayana & $27 \%$ & $24 \%$ \\
\hline Triyana (Western Buddhist) & - & $5 \%$ \\
\hline Non-sectarian & $14 \%$ & $2 \%$ \\
\hline
\end{tabular}

BuddhaNet does not use the Triyana classification; however, my own summary of groups in 1998 identified $2 \%$ of Australia's Buddhist groups as part of this category. ${ }^{6}$ There is a large difference in the number of non-sectarian groups in both countries; it is probable that non-sectarian organisations such as hospices, social action groups, libraries, bookstores and journals are not large enough to be independent groups in New Zealand and are consequently classified as part of the lineage or tradition to which they have some connection. 
There are a number of factors affecting Buddhism's development in Australia and New Zealand. Examination of the ethnicity of Buddhists shows that immigration has been a key contributor. Direct comparison of the ethnicity of Buddhists in New Zealand and Australia is slightly difficult as the available data on Australian Buddhists ethnicity classifies by birthplace, whilst New Zealand census data classifies by ethnicity. Nevertheless, comparison of this data provides a useful starting point, and is contained in Table 2.

Table 2: Comparison of the Birthplace on Australian Buddhists and the Ethnicity of Buddhists in New Zealand

\begin{tabular}{|c|c|c|c|}
\hline $\begin{array}{c}\text { Australian } \\
\text { Category: } \\
\text { by birthplace }\end{array}$ & $\begin{array}{l}\text { \% of Australian } \\
\text { Buddhist pop. }\end{array}$ & $\begin{array}{c}\text { New Zealand } \\
\text { Category: } \\
\text { by ethnicity }^{8}\end{array}$ & $\begin{array}{c}\text { \% of New Zealand } \\
\text { Buddhist pop. }\end{array}$ \\
\hline \multirow[t]{3}{*}{ Australia } & 19.7 & NZ European & 9.3 \\
\hline & & NZ Maori & 2.3 \\
\hline & & European & 4.2 \\
\hline Vietnam & 31 & Vietnamese & 4.9 \\
\hline Indonesia & 2.2 & Indonesia & 0.2 \\
\hline Malaysia & 7.5 & Malaysian & 1.9 \\
\hline Sri Lanka & 5.2 & Sri Lankan & 5.8 \\
\hline Thailand & 6.2 & Thai & 7 \\
\hline Cambodia & 6.8 & Cambodian & 10.7 \\
\hline Laos & 3.4 & Lao & 3.7 \\
\hline China & 4.6 & Chinese & 39.7 \\
\hline Taiwan & 2.5 & Taiwanese & (not stated) \\
\hline Japan & $($ not stated $->2.2 \%)$ & Japanese & 4.9 \\
\hline Korea & $($ not stated $->2.2 \%)$ & Korean & 2.4 \\
\hline Other & 10.9 & Other & 3 \\
\hline
\end{tabular}


Since the vast majority of Australian and New Zealand Buddhists were either born in or identify ethnically with an Asian country, these figures indicate that ethnic Buddhists far outweigh convert Buddhists. Exact figures are not known; however, ethnic Buddhists in Australia have been estimated at $85 \%$; the New Zealand percentage is probably similar. However, the census only identifies those people who classify themselves as Buddhists. Other studies demonstrate that many more people in Western countries practice Buddhism to varying degrees. ${ }^{9}$ For example, Fronsdal notes that many Americans of European descent practising vipassana do not refer to themselves as students of Buddhism. ${ }^{10}$ Similarly Hughes, Black and Kaldor presents evidence that that $11.5 \%$ of $0 \%$ of the Australian population had practised some form of Eastern meditation (although not necessarily Buddhist) in the previous twelve months. ${ }^{11}$

Another major reason affecting the development of Buddhism in these two countries has been the sociocultural context in which both converts and immigrants practice Buddhism. Both Australia and New Zealand are considered multicultural, religiously plural and predominantly secular. The 1989 National Agenda on Multiculturalism affirmed the right of all Australians to express and share their religion "within carefully defined limits". ${ }^{12}$ New Zealand claimed multiculturalism in the 1980s although contemporary government publications now also emphasize biculturalism in recognition of the status of the indigenous Maori population. Multiculturalism has meant that Buddhism has a fertile ground in which to grow, as have other world religions of recent importation. As demonstrated in Table 3, while the number of Buddhists in Australia increased by 43\% between 1991 and 1996, Hindus increased 54\% and Muslims increased 36\%. In New Zealand, while Buddhists increased 120\% from the 1991 figure, Hinduism increased dramatically from $0.2 \%$ to $0.7 \%$ and Islam grew by $50 \%$.

Table 3: Percentages of Adherents of Major Religions in Australian and New Zealand Populations in 1996

\begin{tabular}{|l|c|c|}
\hline & Australia $^{13}$ & New Zealand $^{14}$ \\
\hline Christianity & $70.3 \%$ & $60.5 \%$ \\
\hline Buddhism & $1.1 \%$ & $0.8 \%$ \\
\hline
\end{tabular}




\begin{tabular}{|l|l|l|}
\hline Hinduism & $0.4 \%$ & $0.7 \%$ \\
\hline Islam & $1.1 \%$ & $0.4 \%$ \\
\hline
\end{tabular}

There are other reasons for the religious plurality that exists in both countries. Both Australia and New Zealand have not had state religions dominating the scene, and like many other Western countries, mainstream religions are on the decline. Bouma provides some other reasons, noting that Australia has a lack of overlap between ethnic and religious difference, depoliticisation of religious difference, and a long history of non-violent religious/ethnic conflict. ${ }^{15}$

These sociocultural conditions have also resulted in the rise of many New Religious Movements (NRMs) in both countries. New Age spirituality has been another growth area. In 1985, based on analysis of New Zealand census data, Hill and Bowman concluded: "While there has been a marked decline in both membership and participation in church-type religious groups there has also been a rapid increase in sectarian and cultic groups." ${ }^{16}$ NRMs and New Age Spirituality are often considered to deviate from the norm, and thus attract those members of society who are not satisfied by mainstream religion. However, it is now being argued that many of these organisations are successful because they reflect and incorporate elements of mainstream society that the dominant religions do not. To some degree, these alternative religions are now more mainstream than established religion. For example, Hill argues that New Age spirituality has arisen out of contemporary society rather than the traditional understanding that it is a reaction to it: "There is a great deal of resonance too between cultic groups of this kind and the urban social environment of contemporary New Zealand: for this reason it makes sense to treat them not as deviant responses of opposition to the dominant culture, but as groups which articulate the experience of a substantial part of the population. ${ }^{17}$

While these arguments are usually applied to NRMs and New Age spirituality, they can also be used to explain the growth of Buddhism in the West. While scholars studying NRMs often include Buddhism in their classification, and a few Buddhist scholars employ this classification themselves, many Buddhist scholars disagree with this categorization. It is argued that Buddhism is not a NRM in the West because while it may be new in Western countries, Western groups descend directly from long-established Asian traditions. However, the factors identified as 
responsible for the rise and success of NRMs in the can also be identified for Buddhist groups in the West, and convert Buddhism in particular.

The argument that many NRMs and New Age spirituality now reflects mainstream culture more than it deviates from it may be useful to understanding the rise of convert Buddhism. Recent studies examining the development of Buddhism in countries such as the United States of America, Germany, South Africa and Australia have identified common trends in adaptation. ${ }^{18}$ Queen's identification of the features of the emerging American Buddhism classifies these characteristics as: democratization, pragmatism and engagement; these are similar to those identified elsewhere. ${ }^{19}$ Democratization refers to the emphasis on lay practice and feminization; pragmatism incorporates the emphasis on ritual practices (particularly meditation, chanting, devotional and ethical activities); and engagement refers to the broadening of spiritual practice to include both family and community and the social and environment concerns of the broader world.

With the exception of some ritual practices, these characteristics all seem to fit with Western cultural values, assisting Buddhism's integration into Western culture. Baumann has demonstrated that some German Buddhists have interpreted and presented Buddhism in a way that conforms with and reflects German cultural values and attitudes; ${ }^{20}$ it seems probable that this is the case in each Western country. In a similar vein, a number of scholars have examined Buddhism in the West and concluded that this is "Protestant Buddhism"; that some Buddhist groups have a liberal Protestant outlook, and their Buddhism affirms these values. ${ }^{21}$ Indeed, the Auckland Shambhala Centre in New Zealand writes: "A unique quality of the Buddhist teachings is that they can be expressed through existing cultural norms, making use of them rather than destroying or replacing them. This allows many westerners to practice Buddhism today without renouncing their cultural heritage or radically changing their lifestyles." ${ }^{22}$ Similar to some other Western Buddhist groups (particularly some Vipassana groups), the Auckland Shambhala Centre offers meditation within a secular setting (Shambhala Training), in addition to Buddhist practices.

Buddhist groups in Australia and New Zealand show some degree of conformity to the 
characteristics described by Queen. My own study of the characteristics of Buddhism in Australia concluded that examples of each of these characteristics is evident; however, further research must be undertaken before it can be concluded that these are more than isolated cases. ${ }^{23}$ In the case of New Zealand, no research has been done. However, like the Australian situation, examples can certainly be found. My own analysis of the development of Buddhism in New Zealand indicates that the New Zealand situation is similar to that in Australia; a few characteristics can be seen as obvious patterns, but most are not.

An example of adaptation to the sociocultural context is the Maitai Zendo, the main center for the Diamond Sangha (the Zen Buddhist network founded by Robert Aitken) in New Zealand. The Maitai Zendo is innovative in many areas. The group's teacher, Mary Jaksch Sensei is the first female Zen Master in New Zealand, and only the third female Zen Master in the Diamond Sangha lineage. As part of the broadening of practice to include wider concerns that is one the characteristics of Western Buddhist groups, Buddhist teachings and practices are often synthesized with other disciplines to widen their application. An emphasis on health and healing, particularly in co-operation with psychology, is a common amalgamation. The Maitai Zendo runs a healing group led by the teacher and practising psychotherapist, Mary Jaksch, which is integrated with Zen practice. One practitioner describes some of the practices: "We move into the silence of Zazen. Directly experiencing the breath of life. Then on to the other healing part - the laying on of hands. It sounded so audacious to me, however the instructions were quite simple; hands in gassho, feel the warmth generated between the hands, and slowly lower them to another body." ${ }^{24}$ The Maitai Zendo is also experimenting with new ways of teaching, and since 1999 has offered a Zen Distance Training program to students who would like to practice Zen but who are prevented by distance or circumstance from working with a Zen teacher. Much of the communication between student and teacher is carried out via email, although students are also expected to attend at least one retreat with the teacher each year in person. In additional to traditional Zen practices, students are encouraged to take up areas such as bodywork, creative skills and compassionate action. This last category of ethical action incorporates activities such as helping at local youth centers, joining Amnesty International, or becoming involved with environmental protection, which is another common characteristic of Western Buddhist groups. 
An Australian Buddhist center of note for its innovative ideas for upholding and spreading the Dharma is BuddhaNet (www.buddhanet.net), an internet site founded by Australia's e-monk, the Venerable Pannyavaro:

BuddhaNet is the result of a vision to link up with the growing world-wide culture of people committed to the Buddha's teachings and lifestyle, as an on-line cyber sangha. In this way, an ancient tradition and the information superhighway will come together to create an electronic meeting place of shared concern and interests. .... BuddhaNet is a nonsectarian organisation, offering its services to all Buddhist traditions. It aims to facilitate a significant Buddhist presence in the ever-expanding realm of computer communications technology, applying this technology to helping make the Buddha's teachings freely available to all. ${ }^{25}$

BuddhaNet provides a host of useful resources ranging from the Australia Buddhist Directory used to supply statistics above, a Buddhist magazine, "BuddhaZine", replete with comic strip, to a "What's On" section that lists national events and notices. BuddhaNet is affiliated with the Buddha Dharma Education Association Inc, a Vipassana meditation center in Sydney that is led by the Venerable Pannyavaro.

While the practices of many Australian and New Zealand Buddhist groups seem to reflect the sociocultural context in which they are situated, there are also many examples of traditional practices that have been maintained despite their seeming discord with Australian and New Zealand society. Maintenance of tradition is also vital for ensuring the efficacy and legitimacy of Buddhism in the West. For example, monks at a Thai Forest Tradition monastery in New Zealand, Bodhinyanarama, have continued the practice of going on alms rounds in the surrounding community. Bell provides an excellent analysis of how this practice legitimizes the Thai Forest Tradition in England through emphasis on tradition; a similar case could be argued in New Zealand. ${ }^{26}$ Bodhinyanarama upholds tradition in various other ways; as it is primarily a place of monastic residence it maintains many of the practices of its Thai monastic forefathers. Since the establishment of the monastery in 1985 with two monks from the United Kingdom, the monastery has grown to its current resident community of six bhikkhus, one samanera and three 
anagarikas.

However, in some areas Bodhinyanarama exhibits considerable adaptation to the New Zealand environment, reflecting some of the characteristics identified by Queen. For example, democratization is demonstrated in the existence a Women's Meditation Group, which meets weekly. The Women's Meditation Group has recently hosted weekend retreats with visiting teachers including Anja Tactor, a resident lay teacher at Wat Buddha Dhamma in Australia. While Wat Buddha Dhamma is a Theravada Buddhist center, it is not part of the Thai Forest Tradition lineage, demonstrating a willingness to dialogue with other lineages that is commonly seen in some Buddhist groups in Western countries. A degree on engagement, in relation to the environment concerns of the broader world, can be seen in Bodhinyanarama's Forest Management Strategy. The monastery's property is considered to be important ecologically due to its wide diversity of indigenous plant species and the habitat that it provides for native birds. Because of this the Wellington Theravada Buddhist Association, the charitable trust supporting and administering the monastery, has decided to designate the monastery as a Native Reserve in order to protect, enhance and restore the land on which the monastery is located.

While Queen's characteristics are more commonly identified in groups that are more open to adaptation to the new host culture, particularly convert groups, other interesting example can also be found. Karma Choeling, the first Karma Kagyu Trust monastery in New Zealand, has strong links to its parent center that have resulted in an emphasis on the maintenance of tradition. But emphasis on characteristics such as engagement can be identified here and there in unusual ways. In one center newsletter, a student of the Venerable Lama Samten's recounts an amusing and illustrative tale: in 1993 New Zealand's hydroelectric supply was worrying low; a cause of great concern to a country with a high degree of dependency on this form of electricity. At this time, the Venerable Lama Karma Samten asked if he could visit Lake Tekapo, a key area of hydro electric generation:

What was unusual about this request was that he said he might be able to do something towards ending the electricity crisis! ... He told me he wanted to do practices to placate the spirits that lived in that area, in particular nagas. ... He thought the natural balance of the 
MacKenzie Basin had been upset and these beings weren't very happy. In the weeks leading up to our arrival, Lama said he had established contact with these spirits and they were expecting us. ${ }^{27}$

The Lama identified the land behind the Church of the Good Shepherd as the ideal site for the required fire puja but the local vicar vehemently denied his request to use the site. However, the

local police constable granted permission and the puja was performed. A week afterwards, the lakes had reached a comfortable level and the hydroelectric power problems were over.

Analysis of the development of Buddhism in Australia and New Zealand indicates many similarities between the two countries. A variety of Buddhist groups exist in both countries; some maintain strong connections with the traditions from which they have developed, others demonstrate significant adaptation to the local culture. While both Australia and New Zealand ostensibly support religious diversity, the need for imported religions to adapt to their new surroundings have seen many adaptations that reflect Western values and beliefs. Buddhism may have initially been attractive to some people because of its oriental otherness; however, adaptation to Western culture values is making it more and more acceptable to the mainstream.

\section{Bibliography}

Adam, Enid L. Buddhism in Western Australia. Perth: The Author, 1995.

Adam, Enid and Philip J. Hughes, The Buddhists in Australia. Canberra: Australian Government Publishing Service, 1996.

Bucknell, Roderick S. "The Buddhist Experience in Australia.” In Religion and Multiculturalism in Australia: Essays in Honour of Victor Hayes, edited by Norman Habel, 214-224. Adelaide: Australian Association for the Study of Religions, 1992.

"Engaged Buddhism in Australia." In Engaged Buddhism in the West, edited by Christopher S. Queen, 468-481. Boulder: Wisdom, 2000.

"BuddhaNet's Directory of New Zealand Buddhist Centers." n.d. http://www.buddhanet.net/nzbudir1.htm

Croucher, Paul. Buddhism in Australia 1848-1988. Kensington, New South Wales: New South Wales University Press, 1989. 
Humphreys, Robert and Rowland Ward. "Buddhism." In Religious Bodies in Australia, edited by Robert Humphreys and Rowland Ward, 203-212. 3rd ed. Melbourne: The Authors, 1995.

Lyall, Graeme. "Buddhism in Australia." n. d. http://www.zip.com.au/ lyallg/index.htm.

McDonnell, Terrance and Rod Bucknell, "Buddhists," in Ian Gillman, ed., Many Faiths, One Nation: A Guide to the Major Faiths and Denominations in Australia (Sydney: Collins, 1988), 318-331.

Pannyavaro, Venerable. "BuddhaNet's Buddhist Australia Directory” September 2000. www.buddhanet.net/buds_aus.htm

Spuler, Michelle. "Buddhism in Australia: A Bibliography." 17 June 2000. www.spuler.com/ mspuler/biblio.htm

Spuler, Michelle. "Characteristics of Buddhism in Australia." Journal of Contemporary Religion 15, no. 1 (2000), 29-44.

Viradhammo, Ajahn. "Buddhism." In Religions of New Zealanders, edited by Peter Donovan, 3245. Palmerston North, New Zealand: Dunmore, 1990.

${ }^{1}$ Paul Croucher, Buddhism in Australia 1848-1988 (Kensington, New South Wales: New South Wales University Press, 1989). Other publications include Michelle Spuler, "Characteristics of Buddhism in Australia," Journal of Contemporary Religion 15, no. 1 (2000), 29-44; Enid Adam and Philip J. Hughes, The Buddhists in Australia (Canberra: Australian Government Publishing Service, 1996); Enid L. Adam, Buddhism in Western Australia (Perth: The Author, 1995); Roderick S. Bucknell, "The Buddhist Experience in Australia," in Norman Habel, ed., Religion and Multiculturalism in Australia: Essays in Honour of Victor Hayes (Adelaide: Australian Association for the Study of Religions, 1992), 214-224; Robert Humphreys and Rowland Ward, "Buddhism," in Religious Bodies in Australia, 3rd ed. (Melbourne: The Authors, 1995), 203-212; and Terrance McDonnell and Rod Bucknell, "Buddhists," in Ian Gillman, ed., Many Faiths, One Nation: A Guide to the Major Faiths and Denominations in Australia (Sydney: Collins, 1988), 318-331.

2 Ajahn Viradhammo, "Buddhism" in Peter Donovan (ed.), Religions of New Zealanders (Palmerston North, New Zealand: Dunmore, 1990), 33-34 and 43-45.

${ }^{3}$ Prebish provides an excellent discussion of the use of the terms, convert and ethnic, in Charles S. Prebish, Luminous Passage: The Practice and Study of Buddhism in America (Berkeley: University of California Press, 1999) 57-63.

4 "Buddhist Council of New South Wales: Its Past, Present and Future," n.d., http://www.buddhistcouncil.org/bcgrnd.htm, accessed on 20 September 2000.

5 Dean Jones, "Statistics on Australian Buddhist Organisations," 2000. www.buddhanet.net/badstats.htm, accessed on 17 July 2000. A more detailed breakdown on the traditions and lineages present in Australia in 1998 is available in Spuler, "Characteristics of 
Buddhism in Australia," 31.

${ }^{6}$ Ibid., 32.

${ }^{7}$ Philip J. Hughes, Religion in Australia: Facts and Figures (Kew, Victoria: Christian Research Association, 1997), 17.

${ }^{8}$ Statistics New Zealand "6.4 Religion and Ethnicity," 1996 Census of Population and Dwellings: Ethnic Groups (Wellington, New Zealand: Statistics New Zealand, 1997), 106-114.

${ }^{9}$ Tweed examines difficulties in defining Buddhists in Western countries in Thomas A Tweed, "Night-Stand Buddhist and Other Creatures: Sympathizers, Adherents, and the Study of Religion," in Duncan Ryuken Williams and Christopher S. Queen, eds., American Buddhism: Methods and Findings in Recent Scholarship (Richmond, United Kingdom: Curzon Press, 1999), 71-90.

${ }^{10}$ Gil Fronsdal, "Insight Meditation in the United States," in Charles S. Prebish and Kenneth K. Tanaka, eds., The Faces of Buddhism in America (Berkeley: University of California Press, 1998), 164.

${ }^{11}$ Philip Hughes, Alan Black and Peter Kaldor, "Responses to the Multiplicity of Faiths in Australia," South Pacific Journal of Mission Studies 23 (April 2000), 17.

${ }^{12}$ Quoted in National Multicultural Advisory Council, Multicultural Australia: The Next Steps Towards and Beyond 2000, vol. 1 (Canberra: Australian Government Publishing Service, 1995), 2.

${ }^{13}$ Hughes, Religion in Australia: Facts and Figures.

${ }^{14}$ Statistics New Zealand, "6.4 Religion and Ethnicity," 106-114.

${ }^{15}$ Gary D. Bouma, "The Emergence of Religious Plurality in Australia: A Multicultural Society," Sociology of Religion 56, no. 3 (1995), 297.

16 Michael Hill and Richard Bowman, "Religious Adherence and Religious Practice in Contemporary New Zealand: Census and Survey Evidence," Archives de Sciences Sociales des Religions 50, no.1 (1985), 109.

${ }^{17}$ Michael Hill, "Religion and Society: Cement or Ferment," in Christopher Nichol and James Veitch, eds., Religion in New Zealand, 2nd ed. (Wellington: Tertiary Christian Studies Programme of the Combined Chaplaincies and the Religious Studies Department, Victoria University, 1983), 276.

${ }^{18}$ For information on the United States of America refer to: Prebish, Luminous Passage: The Practice and Study of Buddhism in America; Richard Seager, Buddhism in America (New York: Columbia University Press, 1999); Williams and Queen, American Buddhism: Methods and Findings in Recent Scholarship; and Prebish and Tanaka, The Faces of Buddhism in America. For Europe, refer to: Martin Baumann, "Creating a European Path to Nirvana: Historical and Contemporary Developments of Buddhism in Europe," Journal of Contemporary Religion 10, no. 1 (1995), 55-70; Detlef Kantowsky, "Buddhist Modernism in the West/Germany," in Ulrich Everding, ed., Buddhism and Christianity: Interactions Between East and West (Colombo: Goethe-Institut, 1995), 101-115; and Stephen Batchelor, The Awakening of the West: The Encounter of Buddhism and Western Culture (Berkeley, California: Parallax Press, 1994); South Africa: M. Clasquin and J. S. Kruger, eds., Buddhism and Africa (Pretoria: Unisa Press, 1999); and Australia: Spuler, "Characteristics of Buddhism in Australia".

${ }^{19}$ Christopher S. Queen, "Introduction," in Duncan and Queen, American Buddhism: Methods 
and Findings in Recent Scholarship, xix.

${ }^{20}$ Martin Baumann, "Culture Contact and Valuation: Early German Buddhists and the Creation of a 'Buddhism in Protestant Shape'," Numen 44 (1997), 287.

${ }^{21}$ A good overview is provided in Martin Baumann, "Adapting a Religion in a Foreign Culture: Rationalistic Interpretation of Buddhism in Germany," in Ulrich Everding, ed., Buddhism and Christianity: Interactions Between East and West, 72-100.

22 Auckland Shambhala Study Group, "The Buddhist Path of Practice and Study," n. d. http://msnhomepages.talkcity.com/dharmadr/dlugose/dharmadhatu.htm, accessed on $15 \mathrm{July,}$ 2000.

${ }^{23}$ Spuler, Characteristics of Buddhism in Australia", 41.

24 "Healing Group," Maitai Zendo News 3, no. 1 (1998), 4.

25 "BuddhaNet," n.d., http://www.buddhanet.net/about_bn.htm, accessed on 18 September 2000.

${ }^{26}$ Sandra Bell, "Being Creative With Tradition: Rooting Theravaada Buddhism in Britain," Journal of Global Buddhism 1 (2000), 1-30. http://jgb.la.psu.edu/contents.html, accessed on 21 July 2000.

${ }^{27}$ John Herrett, "Ven. Lama Karma Samten's Visit to Lake Tekapo, Winter '93," n.d., http://www.kagyu.org.nz/content/ktc-laketekapo.html, accessed on 18 September 2000. 